\title{
Specific methanogenic activity of halophilic and mixed cultures in saline wastewater
}

\author{
${ }^{* 1}$ R. Riffat and ${ }^{2}$ K. Krongthamchat \\ ${ }^{1}$ Civil and Environmental Engineering Department, George Washington University, Washington, DC., USA \\ ${ }^{2}$ Environmental Health Science Department, Khon Kaen University, Khon Kaen, Thailand
}

Received 11 October 2005; $\quad$ revised 11 November 2005; $\quad$ accepted 25 November $2005 \quad$ available online 22September 2005

\begin{abstract}
Wastewater containing high concentrations of salt, are difficult to treat using biological treatment processes, especially anaerobic processes. Limited information is available on methanogenic activity in saline environments. The objective of this research was to investigate the activity of halophilic methanogens, digester sludge and a mixed culture of halophilic and methanogenic bacteria, at various levels of salinity, in terms of lag period and specific methanogenic activity (SMA) at two temperatures. For the halophilic bacteria at $35^{\circ} \mathrm{C}$, the initial SMA ranged from 0.46 to $0.90 \mathrm{~g}$ acetate/g VSS $\mathrm{d}$, but decreased at higher salt concentrations. The maximum SMA varied from 1.2 to 2.08 g acetate/g VSS $d$. High sodium chloride concentrations had a significant adverse effect on digester sludge. At $25^{\circ} \mathrm{C}$, at salt concentrations of $30 \mathrm{~g} / \mathrm{l}$ and above, the digester sludge could not acclimate even in 50 days. Little difference was observed in the maximum SMA of mixed culture and halophilic bacteria at high salt concentrations of $40-50 \mathrm{~g} / \mathrm{l}$.
\end{abstract}

Key words: Anaerobic, halophilic methanogens, salinity, SMA, digester sludge, mixed culture

*Corresponding Author, E-mail: riffat@gwu.edu

\section{INTRODUCTION}

Many industries produce saline wastewater as a by product of process water. The high concentration of salts can cause inhibition of biological processes. High salinity wastewater is often difficult to treat using standard anaerobic treatment processes. High sodium concentrations cause osmotic stress, or inhibit one or more of the reaction pathways in the substrate degradation process. Using methanogenic bacteria from saline environments for seeding the system, is an alternative to reduce the osmotic stress on the bacteria. Numerous studies on saline wastewater treatment have reported that high salt concentration caused severe decreases in substrate removal rates. In an earlier study by Kugelman and McCarty (1965), it was observed that a sodium concentration of approximately $230 \mathrm{mg} / \mathrm{l}$ (10 $\mathrm{mM}$ ) was maximally stimulatory to acetate metabolism, while sodium above $4600 \mathrm{mg} / \mathrm{l}$ (200 mM) was strongly inhibitory. The effect of sodium was investigated on an anaerobic filter treating high salt wastewater from a seafood processing industry (Soto et al., 1993). The result showed that sodium concentration of $14 \mathrm{~g} / \mathrm{l}$ caused $50 \%$ inhibition of methanogenic activity in the filter. Continuous treatment of fishmeal processing wastewater under extreme ammonia concentration, was carried out in an upflow anaerobic filter by Guerrero et al., (1997). Under a maximum loading of $5 \mathrm{~kg} \mathrm{COD} / \mathrm{m}^{3}$.day with a salinity content of approximately $7.5 \mathrm{~g} \mathrm{Cl} / \mathrm{l}, 80 \%$ COD removal efficiency was obtained. Recent work in this area is negligible.

A number of researchers have been using acclimation processes and chemicals to increase the strength of bacteria in saline environments. However, this strategy does not completely solve the problem. Some studies on methanogenesis in marine and brackish sediments indicated that, there are some species of methanogenic bacteria that are still active at high salt concentrations. In addition to anaerobic archaebacteria, halophilic methanogens have been found in hypersaline environments (Zhilina, 1986). A study by Krongthamchat and Riffat (2001) showed that halophilic methanogens isolated from mangrove soil had high potential for anaerobic degradation of organic pollutants in wastewater containing various salt concentrations. The objective of this research was to investigate the effects of salinity on halophilic methanogens, digester sludge and a mixed culture of 


\section{R. Riffat and K. Krongthamchat}

halophilic and methanogenic bacteria. Parameters that were used for comparing the effect of salinity in each culture was (i) lag period, and (ii) Specific Methanogenic Activity (SMA), as described by Hovious (1973) and Hulshoff-Pol et al. (1986). The effect of temperature was also observed. Two sets of temperatures were used, $25 \pm 1^{\circ} \mathrm{C}$ and $35 \pm 1^{\circ} \mathrm{C}$. This research was performed at George Washington University in Washington, DC, USA, between 1999 and 2000.

\section{MATERIALS AND METHODS}

Two types of biomass were used in this research, halophilic biomass and digester sludge. The halophilic biomass was obtained from anaerobic mangrove soil from Thailand, and cultivated in a CSTR (Continuously Stirred Tank Reactor) for 6 months at $35^{\circ} \mathrm{C}$, at a constant $\mathrm{pH}$ of $7.0 \pm 0.2$ and acetate utilization rate (AUR) of $1 \mathrm{~g} / \mathrm{l} \cdot \mathrm{d} .15 \mathrm{~g} / \mathrm{l}$ of $\mathrm{NaCl}$ was fed to the reactor each day. In order to reduce the population of sulfatereducing bacteria in the mangrove soil, $20 \mathrm{mM}$ of molybdate was added to the reactor in a one-time slug dose. Anaerobic digester biomass was obtained from a wastewater treatment plant in Washington, DC. The stock culture of this biomass was cultivated in a $2 \mathrm{l}$ vessel, operated at a $50 \mathrm{~d}$ SRT (Solids Retention Time) and a temperature of $35^{\circ} \mathrm{C}$. The mixed culture was obtained by mixing the halophilic biomass and anaerobic digester biomass in the ratio of 1:2.

Acetate was added as the sole substrate. A nutrient solution/basal media was prepared with the following components, and added to the substrate: $0.5 \mathrm{mg} / \mathrm{l}$ $\mathrm{AlCl}_{3} .6 \mathrm{H}_{2} \mathrm{O} ; 0.5 \mathrm{mg} / \mathrm{l} \mathrm{H}_{3} \mathrm{BO}_{3} ; 10 \mathrm{mg} / \mathrm{l} \mathrm{KI} ; 0.5 \mathrm{mg} / \mathrm{l}$ $\mathrm{CuCl}_{2} .2 \mathrm{H}_{2} \mathrm{O} ; 10 \mathrm{mg} / \mathrm{l} \mathrm{MnCl}_{2} .2 \mathrm{H}_{2} \mathrm{O} ; 0.5 \mathrm{mg} / \mathrm{l}$ $\mathrm{Na}_{2} \mathrm{MoO}_{4} .2 \mathrm{H}_{2} \mathrm{O} ; 0.5 \mathrm{mg} / \mathrm{l} \mathrm{Na}_{2} \mathrm{SeO}_{4} ; 0.5 \mathrm{mg} / \mathrm{l} \mathrm{NH}_{4} \mathrm{VO}_{3}$; $0.5 \mathrm{mg} / \mathrm{l} \mathrm{NaWO}{ }_{4} \cdot 2 \mathrm{H}_{2} \mathrm{O} ; 40 \mathrm{mg} / \mathrm{l} \mathrm{FeCl}_{2} .6 \mathrm{H}_{2} \mathrm{O} ; 10 \mathrm{mg} / \mathrm{l}$ $\mathrm{CoCl}_{2} .6 \mathrm{H}_{2} \mathrm{O} ; 0.5 \mathrm{mg} / \mathrm{I} \mathrm{NiCl}_{2} .6 \mathrm{H}_{2} \mathrm{O} ; 0.5 \mathrm{mg} / \mathrm{ZnCl}_{2} ; 1200$ $\mathrm{mg} / \mathrm{l} \mathrm{NH}{ }_{4} \mathrm{Cl} ; 80 \mathrm{mg} / \mathrm{l}\left(\mathrm{NH}_{4}\right)_{2} \mathrm{HPO}_{4} ; 10 \mathrm{mg} / \mathrm{l} \mathrm{NaPO}_{3} ; 300$ $\mathrm{mg} / \mathrm{l} \mathrm{Na}{ }_{2} \mathrm{~S} .9 \mathrm{H}_{2} \mathrm{O} ; 400 \mathrm{mg} / \mathrm{l} \mathrm{KCl} ; 405 \mathrm{mg} / \mathrm{l} \mathrm{CaCl}_{2} .2 \mathrm{H}_{2} \mathrm{O} ; 10$ $\mathrm{mg} / \mathrm{l} \mathrm{Cystein;}$ and $6000 \mathrm{mg} / \mathrm{l} \mathrm{NaHCO}_{3}$.

The experiments were conducted in $125 \mathrm{ml}$ glass serum bottles sealed with a rubber septum. The serum bottles were incubated until the background acetate was utilized and the corresponding gas was vented. The acetate concentration (7000 mg/l) and sodium chloride in basal medium stock solution were added to each bottle. This level of acetate is sufficient to allow the acetate-converting methanogens to operate at their maximum rate (Speece, 1996). Sodium chloride concentrations of $0,5,10,15,20,25,30,35,40,45$ and $50 \mathrm{~g} / \mathrm{l}$ were used. Each serum bottle contained $50 \mathrm{ml}$ of a basal medium including sodium chloride, substrate and $500 \mathrm{mg} / \mathrm{l}$ biomass. Gas production was measured daily and was thus a measure of methanogenic activity. Two parameters were calculated from the experimental data:

- Lag phase. Lag phase is defined as the time required by bacteria to acclimate to their new environment (Metcalf and Eddy, 2003). In a batch experiment, daily gas production was recorded, and the lag period was the phase prior to exponential gas generation. The purpose of this study was to investigate the length of time required by the bacteria to adapt to the new high stress environment.

- Specific Methanogenic Activity (SMA). SMA refers to the rate at which methanogens degrade substrate to produce methane and carbon dioxide. SMA was calculated from the slope of the methane production curve, and expressed in units of g acetate/g VSS.d. The SMA can evaluate the behavior of the culture in a toxic environment, such as in high sodium chloride concentration. This study focused on the initial and maximum SMA. Both initial and maximum SMA were determined from a linear methane production accumulation slope over the first three days and maximum slope $\left(r^{2}>0.95\right)$, respectively, and divided by the total biomass.

\section{RESULTS}

The lag periods of the three cultures at various sodium chloride concentrations were determined from graphs of gas production versus time. Fig. 1 is an example of such a graph, illustrating daily gas production of halophilic culture for various salt concentrations at $35^{\circ} \mathrm{C}$. Table 1 provides a comparison of the lag period of halophilic, digester sludge and mixed culture for various sodium chloride concentrations and temperatures. At $35^{\circ} \mathrm{C}$ and the same level of sodium concentration, halophilic methanogens and mixed culture were able to acclimate themselves to the salt, in a shorter period of time compared to the digester sludge bacteria. At $25^{\circ} \mathrm{C}$ and sodium chloride concentration more than $20 \mathrm{~g} / \mathrm{l}$, the lag time of mixed culture was less than that of the other cultures. Since halophilic bacteria were obtained from a tropical country, they might be familiar with the higher temperature. For that reason, halophilic bacteria 
Specific methanogenic activity...

required more time for adaptation at $25^{\circ} \mathrm{C}$ in highly saline wastewater. These experimental results correspond to the explanation from Speece (1996). Speece had observed that a temperature as low as $25^{\circ} \mathrm{C}$, prolonged the recovery from the effect of toxics. Temporary inhibition of gas production was greater, significantly lengthening gas production recovery time. Kugelman and McCarty (1965) noted that 10 and $20 \mathrm{mMol}$ of sodium concentrations were the maximum to stimulate and strongly inhibit acetate metabolism, respectively. The present research corroborates their results. All sodium chloride concentrations from this experiment had a significant impact on the daily gas production of digester sludge bacteria. High sodium chloride content caused osmotic stress or inhibited the reaction pathways of the degradation process. So the digester sludge bacteria required a longer time to adapt to the high stress condition. Nyholm et al. (1984) mentioned that the toxic effect of substances increased the lag period of bacterial cultures.

Table 1: The lag period of three groups of bacteria at $35 \pm 1^{\circ} \mathrm{C}$ and $25 \pm 1^{\circ} \mathrm{C}$

\begin{tabular}{|ccccccc|}
\hline \multirow{2}{*}{$\mathrm{NaCl}(\mathrm{g} / \mathrm{l})$} & \multicolumn{5}{c|}{ Lag period (days) } \\
\cline { 2 - 7 } & \multicolumn{2}{c|}{ Halophilic methanogens } & Digester sludge bacteria & Mixed culture \\
\cline { 2 - 7 } 0 & Temp $25 \pm 1^{\circ} \mathrm{C}$ & Temp $35 \pm 1^{\circ} \mathrm{C}$ & Temp $25 \pm 1^{\circ} \mathrm{C}$ & Temp $35 \pm 1^{\circ} \mathrm{C}$ & Temp $25 \pm 1^{\circ} \mathrm{C}$ & Temp $35 \pm 1^{\circ} \mathrm{C}$ \\
5 & 5 & 5 & 6 & 4 & 4 & 5 \\
10 & 4 & 4 & 10 & 5 & 5 & 4 \\
15 & 4 & 4 & 18 & 11 & 5 & 4 \\
20 & 4 & 2 & 42 & 11 & 5 & 4 \\
25 & 6 & 2 & 42 & 12 & 4 & 4 \\
30 & 9 & 2 & 42 & 14 & 4 & 5 \\
35 & 11 & 2 & $50^{+}$ & 14 & 5 & 5 \\
40 & 12 & 4 & $50^{+}$ & 17 & 4 & 7 \\
45 & 15 & 4 & $50^{+}$ & 17 & 6 & 8 \\
50 & 25 & 4 & $50^{+}$ & 23 & 9 & 7 \\
\hline
\end{tabular}

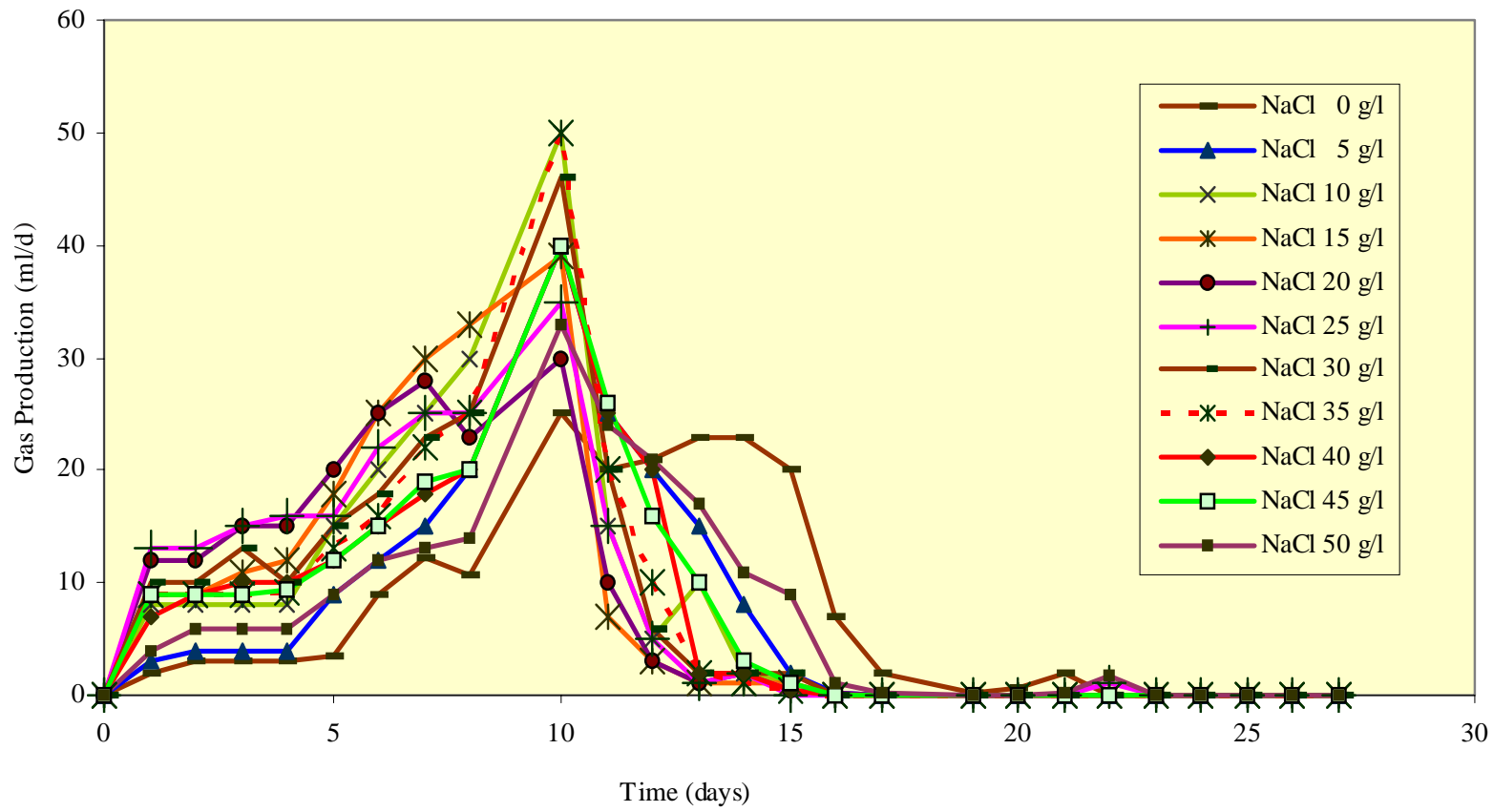

Fig. 1: Daily gas production of halophilic methanogens for various sodium chloride cconcentrations at $35^{\circ} \mathrm{C}$ 


\section{R. Riffat and K. Krongthamchat}

At $25^{\circ} \mathrm{C}$, at salt concentrations of $30 \mathrm{~g} / \mathrm{l}$ and above, the digester sludge could not acclimate even in 50 days. The gas production at high salt concentration was almost negligible. This indicated that a combination of higher sodium content and lower temperature have a strong negative impact on digester sludge. In this study, SMA was classified in terms of initial and maximum SMA. Initial SMA was the result of a short term study, while maximum SMA was obtained from the result of a long term study. In the long term study, bacteria were provided enough time for acclimation to occur. The initial and maximum specific activities for a variety of sodium chloride concentrations at $35^{\circ} \mathrm{C}$ for halophilic bacteria are illustrated in Fig. 2. The SMA values for each salt concentration, was presented as the average of three experimental values. The halophilic methanogens had the ability to utilize substrate even when sodium chloride was not injected in the solution. This indicates that these bacteria have the potential to treat wastewater that normally has a low salt content, but occasionally receives a high salt discharge.
With increasing sodium chloride concentration between the range of $0-25 \mathrm{~g} / \mathrm{l}$, the initial activities increased from 0.46 to $0.90 \mathrm{~g}$ Acetate/g VSS d, but a decrease in activity was observed at higher salt concentrations. The maximum SMA varied from 1.2 to $2.08 \mathrm{~g}$ acetate/g VSS $d$. The highest value was reached by halophilic bacteria, at the concentration of $15 \mathrm{~g} \mathrm{NaCl} / \mathrm{l}$. The time to reach the maximum specific activities occurred between 7 to 10 days at salt concentrations ranging from 10 to $30 \mathrm{~g} / \mathrm{l}$, and had maximum SMA values between 1.6-2.08 g acetate/g VSS·d. The results of this study suggest that the presence of high sodium content in wastewater need not eliminate methanogenesis process as a viable treatment alternative, using the halophilic methanogens. When the SMA value of halophilic bacteria was compared with that of methanogens used in anaerobic reactors, it showed minimal difference. The SMA of methanogens in anaerobic reactors is $2 \mathrm{~g}$ acetate/g VSS·d, while the SMA of halophilic culture from this experiment was $2.08 \mathrm{~g}$ acetate/g VSS·d.

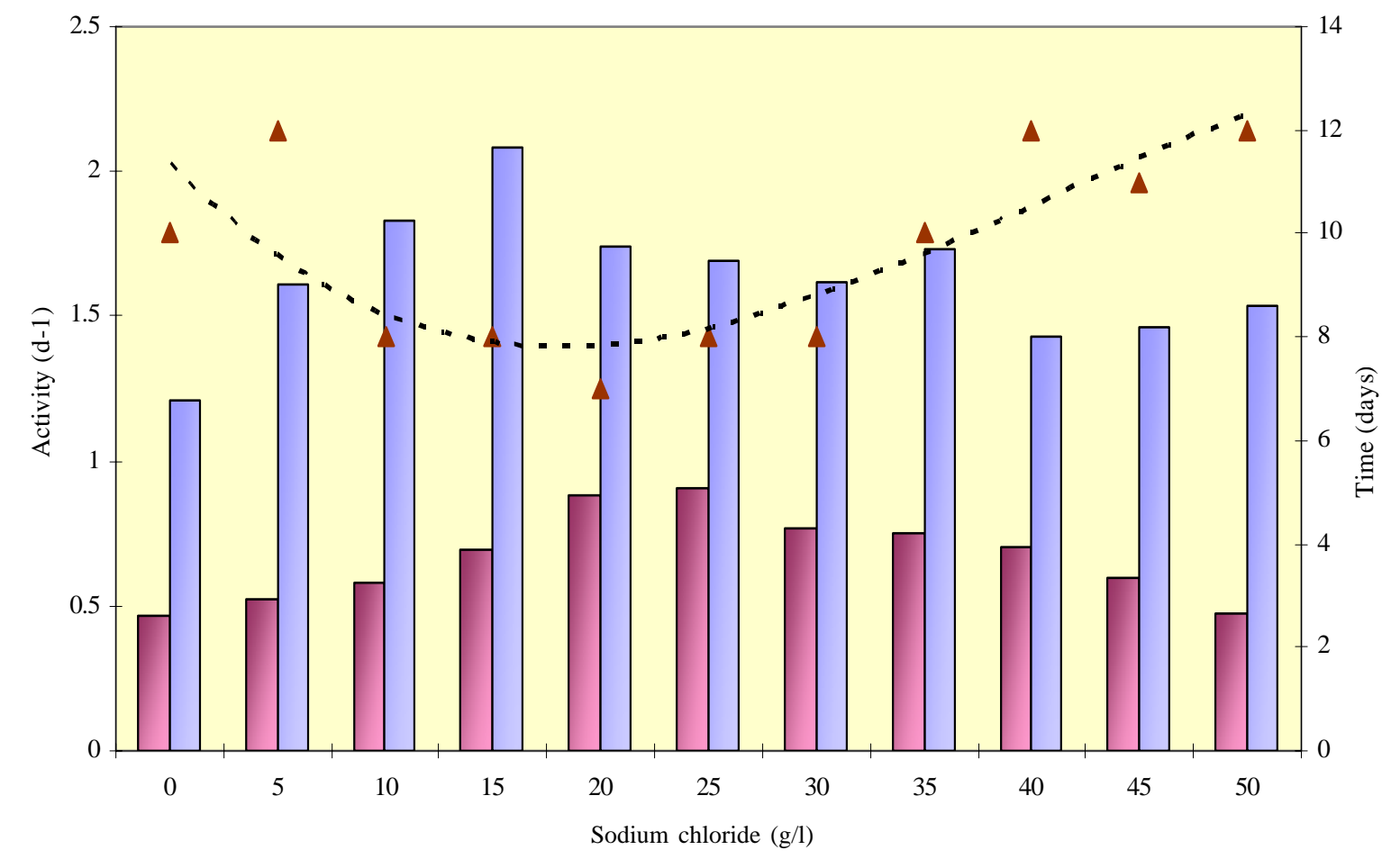

Initial activity $\square$ Maximum activity

$\Delta \quad$ Time to reach maximum activity

- - - Poly. (Time to reach maximum activity)

Fig. 2: Activity of halophilic methanogens for various sodium chloride concentrations at $35^{\circ} \mathrm{C}$ 


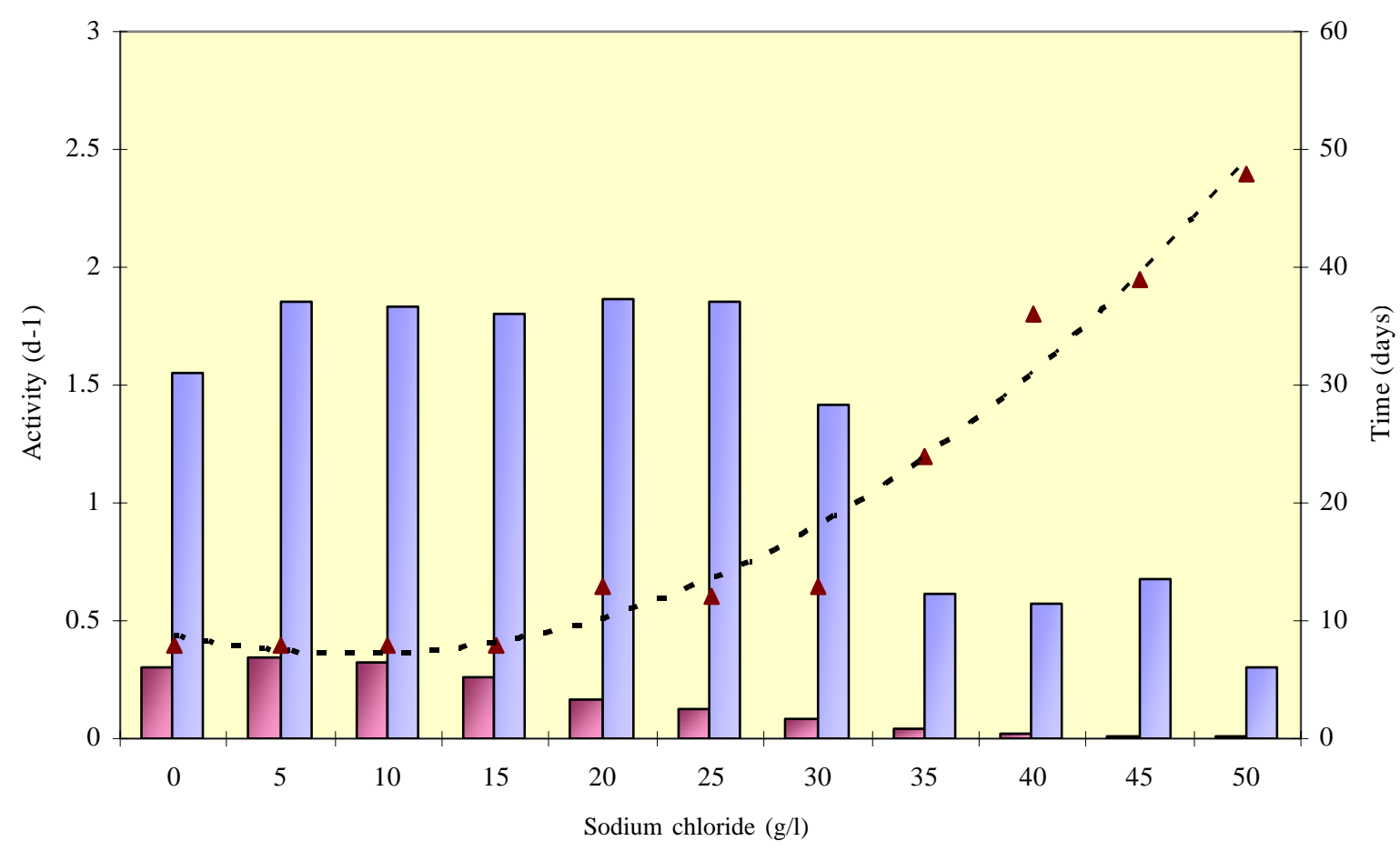

Initial activity $\square$ maximum activity

$\Delta$ Time to reach maximum activity

Fig. 3: Activity of halophilic methanogens for various sodium chloride concentrations at $25^{\circ} \mathrm{C}$

Fig. 3 illustrates the specific activity of halophilic bacteria at $25^{\circ} \mathrm{C}$. Based on the SMA values and the time to recover, more severe effect of sodium chloride was observed at $25^{\circ} \mathrm{C}$, as compared to $35^{\circ} \mathrm{C}$. The initial SMA values of halophilic bacteria were less, when the sodium chloride concentrations were higher. The maximum SMA values at sodium chloride concentrations between $5-25 \mathrm{~g} / \mathrm{l}$ were similar. The maximum SMA in the range of $35-50 \mathrm{~g} \mathrm{NaCl} / \mathrm{l}$, were 3 times less than the values at the prior sodium concentrations. A reduction in temperature from $35^{\circ}$ to $25^{\circ} \mathrm{C}$ magnified the inhibitory effect on methanogenesis process, and reduced the potential of bacteria to acclimate to high sodium chloride concentration, especially in the concentration between 35-50 g/l. The temperature inhibition of gas production was greater, and the time elapsed before the gas production level recovered to normal was significantly greater at the lower temperature of $25^{\circ} \mathrm{C}$. The initial SMA values of digester sludge at $35^{\circ} \mathrm{C}$ were very low, at the various salt concentrations (Fig. 4). The initial activities were reduced to half or less when the salt concentration was more than $10 \mathrm{~g} \mathrm{NaCl} / \mathrm{l}$. In contrast, the highest maximum SMA was $2.5 \mathrm{~g}$ acetate/g VSS·d at the sodium chloride concentrations of 30 - 35 g/l. However, the time to reach this maximum value was 21- 23 days. This showed that digester sludge was able to tolerate the high salinity, but required a long period of time for acclimation. The time to reach the maximum activities was as high as 26-34 days, and the activity fell when the sodium chloride concentration was more than $40 \mathrm{~g} / \mathrm{l}$. Because of the long recovery time, if the bacteria were to be applied to a reactor to treat wastewater containing high salinity, then the reactor should provide the capacity for a long washout period. As the methane production becomes negligible, so does the growth of the methanogens. Consequently, the biomass in the system will be washed out by the daily SRT wastage. During the recovery period, bacterial regeneration is also reduced, as compared to normal conditions (Parkin et al., 1983). Therefore, growth would not be at, as fast a rate to restore biomass to the background concentration. In the case of wastewater containing high salt concentration in normal operation, the startup 


\section{R. Riffat and K. Krongthamchat}

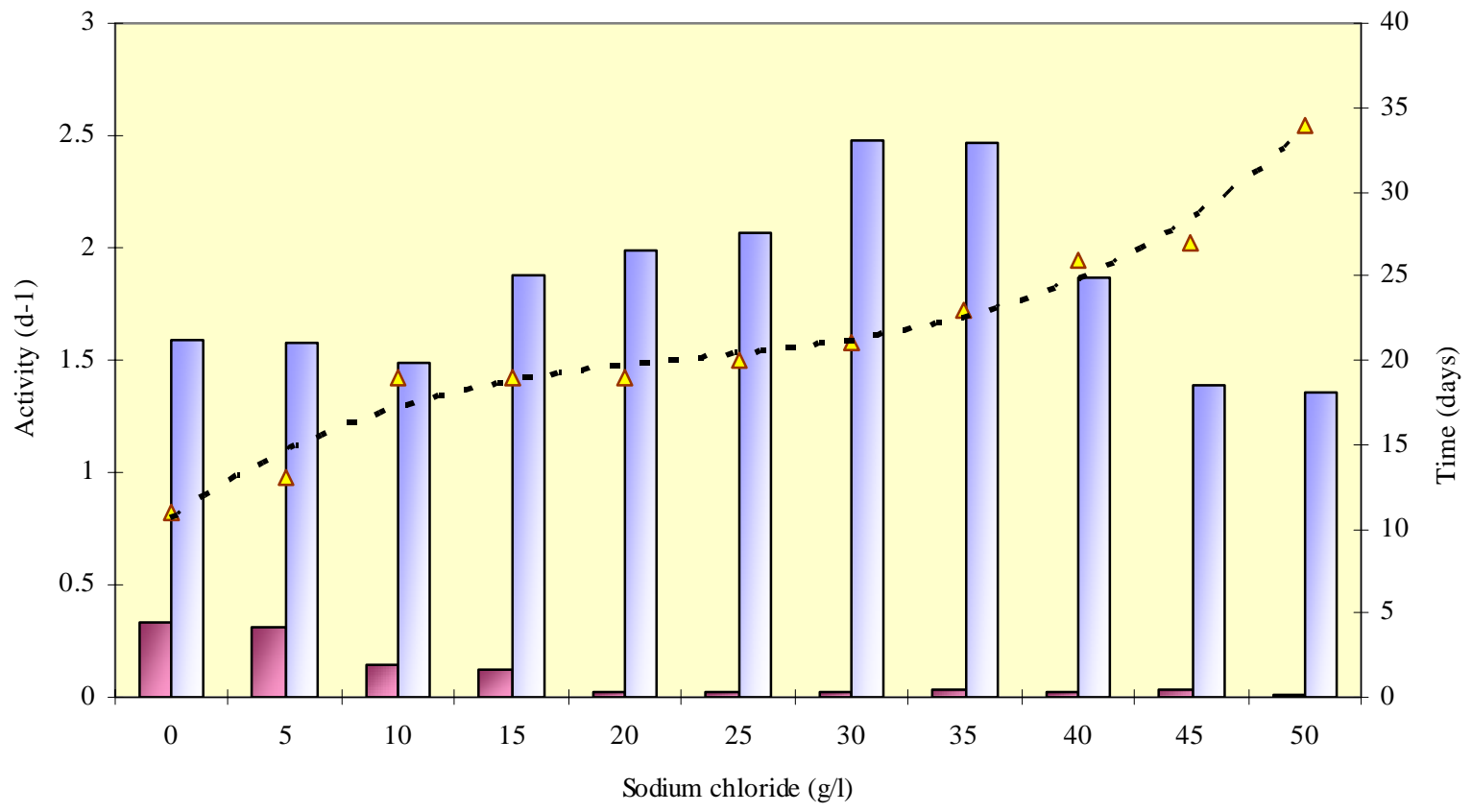

$\square$ Initial activity $\square$ Maximum activity $\Delta$ Time to reach maximum activity

Fig. 4: Activity of digester sludge bacteria for various sodium chloride concentrations at $35^{\circ} \mathrm{C}$

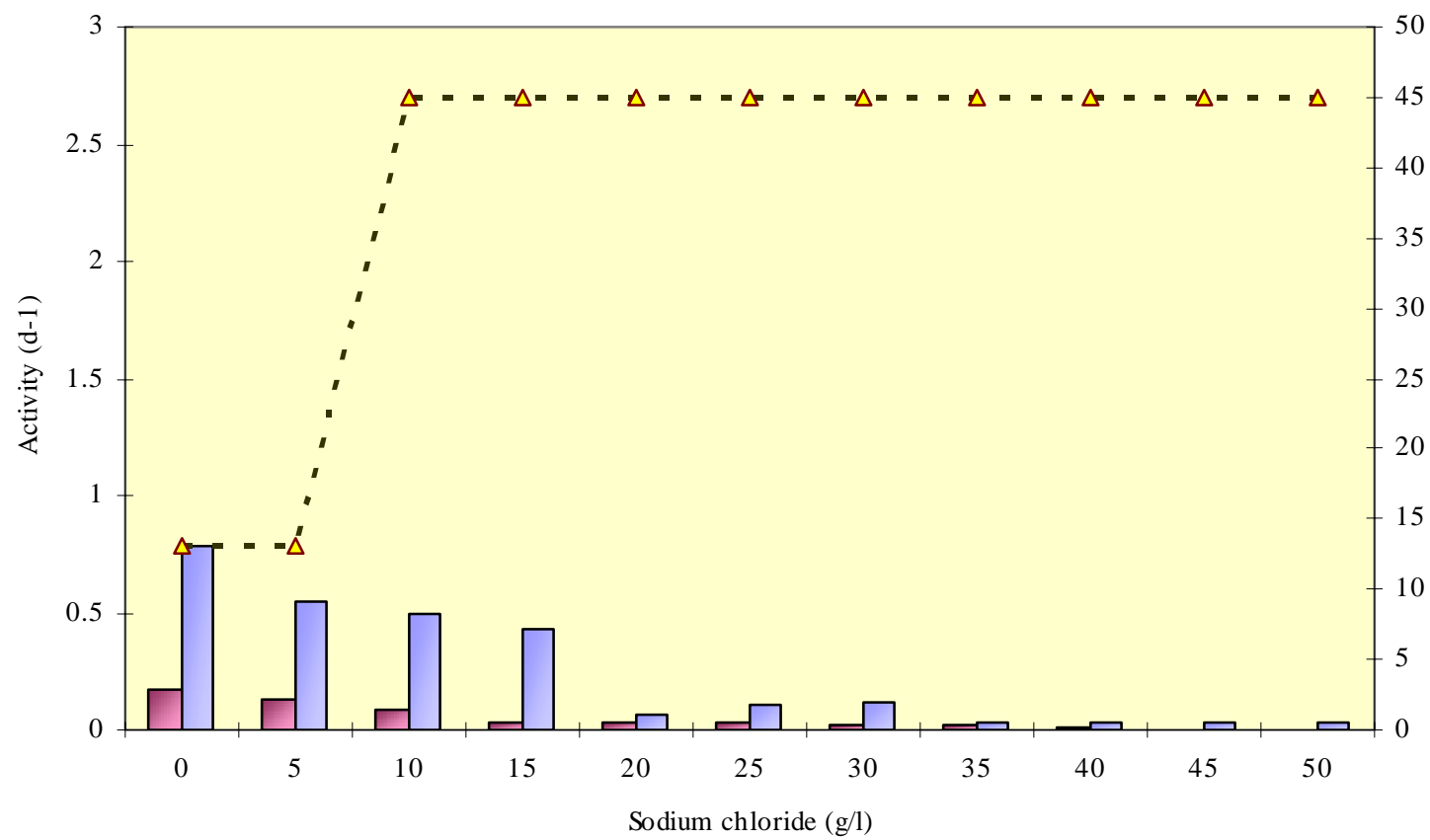

Fig. 5: Activity of digester sludge bacteria for various sodium chloride concentrations at $25^{\circ} \mathrm{C}$ 
Specific methanogenic activity...

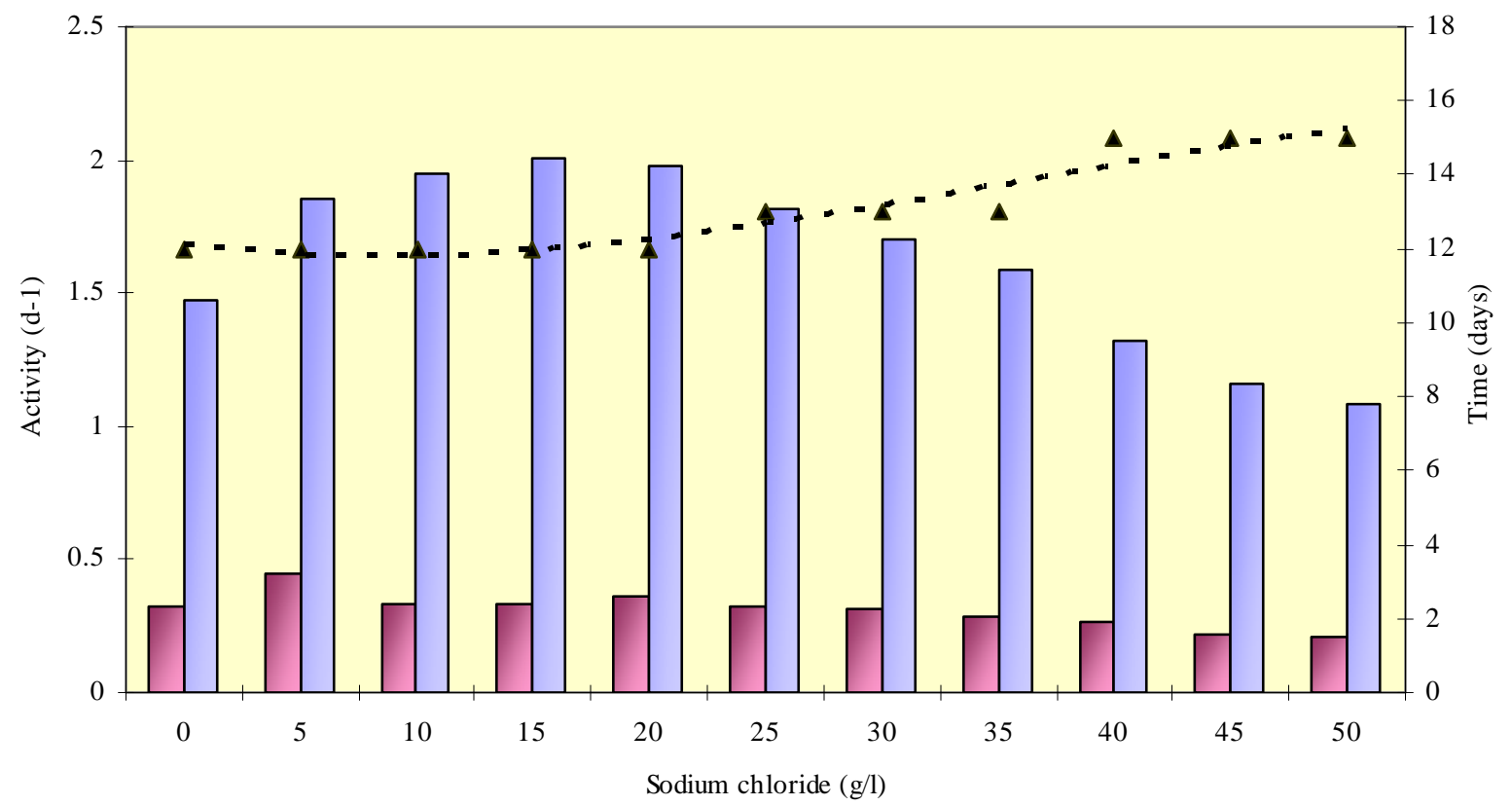

$\square$ Initial activity $\square$ Maximum activity $\boldsymbol{\Delta}$ Time to reach maximum activity

Fig. 6: Activity of mixed culture for various sodium chloride concentrations at $35^{\circ} \mathrm{C}$

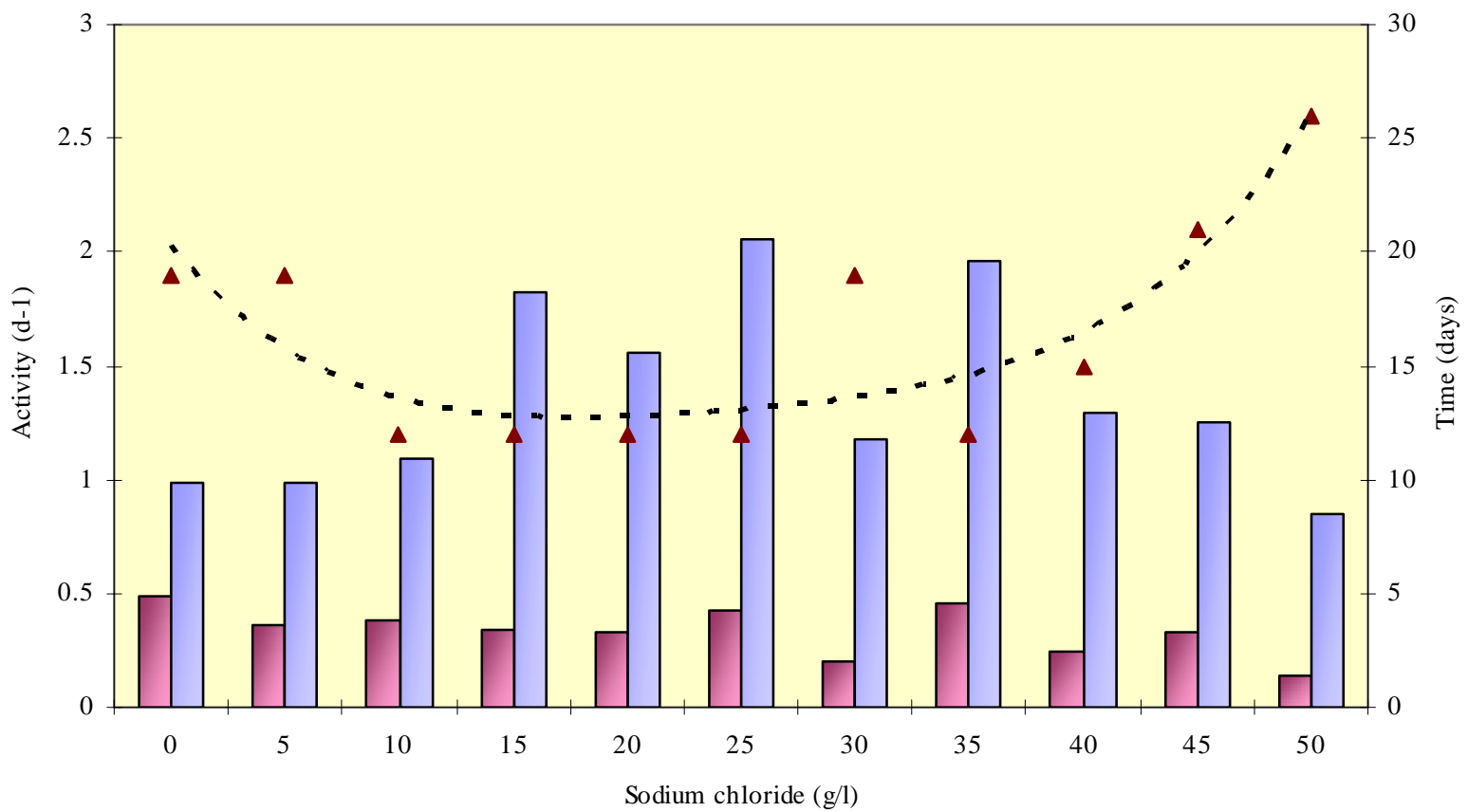

$\square$ Initial activity $\quad \square$ Maximum activity $\quad \Delta$ Time to reach maximum activity

Fig. 7: Activity of mixed culture for various sodium chloride concentrations at $25^{\circ} \mathrm{C}$ 


\section{R. Riffat and K. Krongthamchat}

of the reactor may take a long time. The effect of low temperature $\left(25^{\circ} \mathrm{C}\right)$ on initial and maximum specific activities of digester sludge at various sodium chloride concentrations was quite dramatic, as illustrated in Fig. 5. Bacteria had the highest activity when no salt was added to the medium. The activities decreased when the salt concentration was increased. Both initial and maximum SMA values were nearly zero, at concentrations above $15 \mathrm{~g} \mathrm{NaCl} / \mathrm{l}$. Even after more than 45 days, digester sludge bacteria were not able to increase their activities. Fig. 6 illustrates the specific activities of mixed culture for the various sodium chloride concentrations at $35^{\circ} \mathrm{C}$. The highest initial SMA was observed at $5 \mathrm{~g} \mathrm{NaCl} / \mathrm{l}$, while the initial SMA at all other salt concentrations were similar. The lowest initial SMA was at the highest salt content of $50 \mathrm{~g} / \mathrm{l}$. The maximum specific activities gradually increased from 1.5-2.0 g acetate/g VSS·d, when sodium chloride was raised from 0-15 g/l. The maximum SMA gradually decreased from 2.0 to $1.08 \mathrm{~g}$ Acetate/g VSS $\mathrm{d}$, when the salt content was increased from 15 - $50 \mathrm{~g} / \mathrm{l}$. The time to reach the maximum specific activities was between 1215 days. The initial specific activities of the mixed culture at $25^{\circ} \mathrm{C}$ varied from $0.14-0.5 \mathrm{~g}$ acetate/g VSS $\cdot \mathrm{d}$ (Fig. 7). The highest maximum SMA occurred between the salt concentrations of 25 and $35 \mathrm{~g} / \mathrm{l}$. These results showed that all three types of cultures were able to tolerate the broad ranges of sodium chloride concentration at $35^{\circ} \mathrm{C}$, but they required different recovery times. Digester sludge needed the longest time to reach the maximum SMA. For example, digester sludge at $20 \mathrm{~g} / \mathrm{l}$ sodium chloride, needed 20 days to reach the maximum SMA of $2 \mathrm{~g}$ acetate/g VSS·d; while the mixed culture required only 12 days to reach the same value of SMA. In general, halophilic bacteria required less time to reach the maximum activities for all sodium chloride concentrations. The mixed culture was able to adapt to the saline environment more quickly than digester sludge bacteria, especially at higher sodium chloride concentrations. The maximum SMA of mixed culture and halophilic bacteria in the salt concentrations of $40-50 \mathrm{~g} / \mathrm{l}$ indicated that, there was very little difference in the activity of these cultures. The time periods to reach the maximum activities were also similar, for these two types of cultures. Temperature had a marked effect on the activity of digester sludge. At $25^{\circ} \mathrm{C}$, the maximum activities were very low at every sodium chloride concentration, except at $0 \mathrm{~g} / \mathrm{l}$. The activities were not increased, even when the bacteria were given more time to acclimate. At $25^{\circ} \mathrm{C}$, the maximum activity of halophilic bacteria was greater than that of mixed culture at concentrations between $0-10 \mathrm{~g} \mathrm{NaCl} / \mathrm{l}$. However, in the high concentration range, maximum mixed culture activity was able to overcome halophilic activity, and used a shorter time to reach the maximum activity.

\section{DISCUSSION AND CONCLUSION}

In this research, the activity of three bacterial populations including halophilic microorganisms, digester sludge and a mixture of halophilic methanogens and digester sludge in the ratio 1 to 2 , was evaluated at various concentrations of sodium chloride, ranging from $0-50 \mathrm{~g} / \mathrm{l}$, at two different temperatures. Based on the results of this research, the following conclusions were drawn:

1. At $35^{\circ} \mathrm{C}$, the shortest lag period of halophilic methanogens was found at salt concentrations of 15$30 \mathrm{~g} / \mathrm{l}$. Lower and higher salt concentrations caused a longer lag time. For the mixed culture, the lag time was insignificant at $\mathrm{NaCl}$ concentrations between 0-35 g/l. Adverse results were found for digester sludge containing more than $5 \mathrm{~g} / \mathrm{l}$ of salt. Increases in sodium chloride concentration increased the lag time significantly.

2. At $25^{\circ} \mathrm{C}$, sodium chloride had an adverse effect on bacteria in terms of lag period, especially for the digester sludge and halophilic methanogens. Higher salt concentrations resulted in longer lag times. At salt concentrations of $30 \mathrm{~g} / \mathrm{l}$ and above, the digester sludge could not acclimate even in 50 days. No significant difference in the lag phase of the mixed culture was observed when the salt concentration was below $45 \mathrm{~g} / \mathrm{l}$. 3. For the halophilic culture, the highest initial SMA (approximately 0.47 g acetate/g VSS d) was observed at sodium chloride concentrations of $20-25 \mathrm{~g} / \mathrm{l}$, at $35^{\circ}$ C. The highest maximum SMA occurred at a sodium concentration of $15 \mathrm{~g} / \mathrm{l}$ (2.08 g acetate/g VSS-d). The initial SMA of digester sludge approached zero at sodium chloride levels of more than $15 \mathrm{~g} / \mathrm{l}$. But the results showed that digester sludge had the ability to reach the highest maximum SMA of 2.5 g acetate/g VSS $d$ at a salt concentration of $35 \mathrm{~g} / \mathrm{l}$. However, the culture required an acclimation time of about 23 days. The mixed culture could operate in a broad range of sodium chloride concentrations (0-50 g/l). The highest maximum SMA for the mixed culture (about $2 \mathrm{~g}$ acetate/ 
Specific methanogenic activity...

g VSS d) was observed at a sodium chloride concentration between 10-20 g/l.

4. The lower temperature of $25^{\circ} \mathrm{C}$ had an adverse effect on all the bacterial populations. Both initial and maximum specific activities were less than those at $35^{\circ}$ C. The initial activity of halophilic bacteria approached zero when the salt concentration was higher than $25 \mathrm{~g} / \mathrm{l}$. The highest maximum SMA of $1.8 \mathrm{~g}$ acetate/g VSS $\mathrm{d}$ was observed, when the sodium chloride concentration was between 5-25 g/l. For the mixed culture, a maximum SMA of $2 \mathrm{~g}$ acetate /g VSS d occurred at a salt concentration of $25 \mathrm{~g} / \mathrm{l}$. Sodium chloride concentrations greater than $5 \mathrm{~g} / \mathrm{l}$ had a severe adverse effect on the digester sludge population. Both the initial and maximum SMA approached zero at salt concentrations above $15 \mathrm{~g} / \mathrm{l}$. The activity of the digester sludge could not recover, even after the culture was acclimated for more than 45 days.

\section{REFERENCES}

Guerrero, L., Omil, F., Mendez, R. and Lema, J. M., (1997). Treatment of saline wastewaters from fish meal factories in an anaerobic filter under extreme ammonia concentrations. Bioresour. Technol, 6 (1), 69.

Hovious, J. C., (1973). Identification and control of petrochemical pollutants inhibitory to anaerobic processes. Environmental protection technology series, EPA-R2-73-194, USEPA, Cincinnati, Ohio.

Hulshoff-Pol, L. W., Van de Worp, J. J. M., Lettinga, G. and Beverloo, W. A., (1986). Physical characterization of anaerobic granular sludge. In: Anaerobic Treatment. A Grown-up Technology. Aquatech, Amsterdam, 89-101.
Krongthamchat, K. and Riffat, R.(2001). Organic biodegradation in saline wastewater using halophile-supplemented methanogenic cultures. Proc. $9^{\text {th. }}$ World Congress Anaerobic Digestion: Anaerobic Conversion for Sustainability, Part 2, Antwerpen, Belgium.

Kugelman, I. J. and Mc Carty, P. L., (1965). Cation toxicity and stimulation in anaerobic waste treatment. J. Wat. Pollut. Control Fed., 37, 97-116.

Metcalf and Eddy, (2003). Wastewater engineering: treatment, Disposal and reuse. $4^{\text {th }}$ Ed. McGraw Hill Inc., New York, USA.

Nyholm, N., Lindgaard-Jorgensen, P. and Hansen, N., (1984). Biodegradation of 4-nitrophenol in standardised aquatic degradation tests. Ecotoxicol. Environ. Saf., 8, 454.

Parkin, G. F., Speece, R. E., Yang, C. H. J. and Kocher, $M$. W., (1983). Response of methane fermentation systems to industrial toxicants. J. Water Pollut. Control Fed., 55 (1), 44.

Soto, M., Mendez, R. and Lema, J. M., (1993). Sodium inhibition and sulphate reduction in the anaerobic treatment of mussel processing wastewaters. J. Chem. Tech. Biotechnol., 58, 1.

Speece, R. E., (1996). Anaerobic biotechnology for industrial wastewaters. Archae Press., Nashville, TN, USA.

Zhilina, T. N., (1986). Methanogenic bacteria from hypersaline environments. Sys. Appl. Microbiol., 7, 216. 